\title{
MANAGEMENT OF A TRANSPORT COMPANY DURING THE COVID-19 PANDEMIC
}

\author{
Paweł BEŁCH \\ Rzeszow University of Technology, Faculty of Management, Department of Management Systems \\ and Logistics, Poland; p.belch@prz.edu.pl, ORCID: 0000-0003-0818-5284
}

\begin{abstract}
Purpose: The end of the first quarter of 2020 is the beginning of a new, difficult time in the functioning of transport companies, as well as the entire Polish and world economy. The appearance of Covid-19 (SARS-CoV-2) resulted in a number of market restrictions and a sharp decline in transport orders. Enterprises had to change the way they were managed and operated, had to adapt to a different economic reality in order to continue to prosper. The aim of the article is to define the essence of managing a transport company in the new market and economic conditions that appeared during the Covid-19 pandemic.
\end{abstract}

Design/methodology/approach: The research procedure included review of polish and foreign literature, analysis of legal acts, questionnaire research, analysis of the content of internal documents of transport companies, method of analysis and synthesis, case study, methods of inductive and deductive reasoning. The article presents the results of scientific research on the impact of Covid-19 on the management and decisions made in a transport company.

Findings: The high level of impact of the Covid-19 pandemic on the management of a transport company has been demonstrated. The factor that most influenced the management and decisions of transport companies is the decline or fear of a decline in contracts for transport services. Transport companies are afraid of the further negative effects of the pandemic, and therefore do not want to take out investment loans in order to develop the company. The article discusses the activities of transport companies and the management of a transport company in crisis conditions.

Research limitations/implications: The article presents a survey carried out in Polish transport companies from the Podkarpackie and Lubelskie voivodships. Therefore, the research results concern the area of south-eastern Poland.

Practical implications: The results of the research may be helpful for managers of transport companies (management decisions made) in order to limit the negative impact of the Covid-19 pandemic on their business activities.

Originality/value: The presented research and conclusions provide practical guidance to managers about what decisions and actions can improve the economic condition of their transport companies in the difficult period of the Covid-19 pandemic, based on the example of the analyzed transport companies.

Keywords: business management, transport company, Covid-19 pandemic, crisis.

Category of the paper: research paper. 


\section{Introduction}

Business management is a set of decisions and activities, very complex and difficult, which is to ensure the proper functioning of the enterprise and generate profit from its activities. A transport company provides services that consist of the commercial transport of people or goods. Transport is one of the most important industries that has a significant contribution to the development of the economy of each country, including Poland. Carriers support the operation of industry and the manufacturing sector, they also increase the level of Gross Domestic Product (GDP). The dynamic development of the TSL (Transport - Forwarding Logistics) industry, which has taken place in recent years, has been very limited since March 2020. The reason for this slowdown is the emergence of the global Covid-19 epidemic (SARS-CoV-2). The restrictions and restrictions introduced in order to fight the coronavirus resulted in a significant decrease in demand for the transport services provided. In this difficult period for entrepreneurs, the management of a transport company gained particular importance. Managers of transport companies had to modify the current and strategic management of the enterprise and adapt it to the new economic conditions. The actions taken were necessary and necessary, they were aimed at restructuring the enterprise, reducing operating costs and reducing expenses. Transport companies had to start to function more efficiently and more efficiently to continue to generate income and prosper in the market, to survive this very difficult period in their history, which it is not known when it will realistically end. The proper management of a transport company is a very difficult task for any manager, especially in this new and uncertain time of the Covid-19 epidemic.

\section{Activities of transport companies}

Transport as a branch of the national economy has a significant impact on its development, in every segment of material production and services. All types of economic activities are related to transport, by transporting people to specific destinations, distribution of products and services, as well as raw materials and materials necessary for the production. Therefore, it contributes to the generation of national income, influencing the dynamics of the production development of enterprises and guaranteeing the implementation of trade in goods (Bełch, 2019). Transport activity is a broad concept, covering many activities thanks to which the cargo will reach from the place of origin to its destination. It is difficult to imagine the world economy, especially in the period of its globalization, without the dense network of transport routes and connections that allow producers, exporters and importers to freely conclude contracts, regardless of where the goods are located and where their future owner is. Those regions of the 
world that do not have roads and transport points cannot take part in international trade and industrial cooperation. Commercial transport activity consists in the provision of transport services, i.e. the paid transport of people or goods and the provision of additional services directly related to it (Neider, 2015). The importance of transport in the economy is constantly growing. This is due to processes such as: specialization and division of labor, competition in the market, pressure to reduce costs, economies of scale of production, mass consumption, development of cooperation, striving to improve customer service and shortening the life cycle of products (Długosz, 2009).

Running a transport company is a challenge that comes with a lot of planning and proper logistics, especially when it comes to international transport. A modern transport company has to cope with many modern tasks. They result from the variety of services provided and the need to regulate the level of prices for these services. However, the greatest importance is attached to ensuring the quality of transport services. This is related to the known paradox between the choice of quality and the price of activities in the transport sector (Gołembska, 2020). A transport company should implement modern equipment and means of transport into its activities. It is a requirement of increasing competition and the rapid development of digitization and robotics in connection with the next industrial revolution, which is referred to as "Industry 4.0". This has a large impact on the ongoing changes in the global economic system, including transport (Strandhagen et al., 2017). The use of intelligent technologies allows for the design of new and more efficient transport processes, products and services (Lee et al., 2015; Hirsch-Kreinsen, 2016). One of the basic factors that determine transport accessibility is also a modern transport infrastructure (Dijkstra, Annoni, Kozovska, 2011).

Each company must define its position on the market of transport services against the competition, and above all (Rosa, 2013; Marecki, Wieloch, 2008):

- identify competitors and assess their strength and threat which they pose or may pose to a given company in the future,

- determine what situation on the market (in the economy) will favor the expansion of other entities.

The transport services market is a comprehensively analyzed and complex issue. It is shaped by the relations between supply and demand, taking into account a specific price level. The transport company must constantly adapt its activities to changing environmental conditions. It should constantly research and analyze the market on which it is located, both in relation to the changes taking place there, and to the relationship of the transport services market with the environment. 


\section{Management of a transport company in crisis conditions}

The year 2020 brought with it many new, unforeseen events related to the emergence of the global Covid-19 pandemic. It is a very hard and difficult period for the world economy, as well as for individual countries and enterprises. The Covid-19 virus not only stopped the development of transport companies, but also prevented their current functioning for several months. In order to survive, transport companies had to learn to function in the new, difficult reality, managers had to learn to manage a transport company in a crisis.

Crisis management is the process of planning and taking actions aimed at reducing the risk associated with the emergence of a crisis or crisis, taking control of the crisis and returning to the pre-crisis state (Grocki, 2020). Of course, the course of the crisis caused by Covid-19 was not significantly influenced by the individual company, but proper management should minimize the negative impact of the crisis on the functioning of the company. The content of the elements of the crisis management model determines the area of crisis management. It mainly concerns such elements as: goal, idea, methods, participants, area (Langinvainio, 2006). K. Fearn-Banks (2007) defines crisis management as a process that minimizes the risk and the degree of uncertainty associated with the occurrence of an adverse event, and thus allows for increasing control over activities related to the fate of the enterprise. New business planning should include a response plan to known events, but you should also be prepared for events whose size and nature cannot be assessed in advance. Changes in the company are also required by the way the team works, which prepares decisions during crisis situations. The management team must have the ability to achieve situational awareness and flexibly select task modules to new crisis conditions (Skomra, 2020). In the case of Covid-19, the situation of transport companies has become very tough and their future uncertain. State authorities, in order to limit the spread of the epidemic, introduced a number of severe restrictions, as a result of which, inter alia, schools, state offices, restaurants, state borders were closed, mass events were canceled, and contact between people was limited to a minimum. This resulted in a significant decrease in demand for transport services. It was possible to observe the occurrence of the logical correlation which is the most difficult to detect. It is the interdependence between the various types of critical infrastructure and between it and the administration. They interact with each other without any physical, digital or geographic connection (Rinaldi, Peerenboom, $\&$ Kelly, 2001). Logical correlations are the most difficult to detect and therefore are often not taken into account at the stage of risk assessment and response planning. Another example of this correlation is the 2009 epidemic of influenza A (H1N1) in Mexico, where restrictions on the spread of the epidemic were not as expected (Lee et al., 2010; Chowell et al., 2011). By managing a transport company in a market economy, the owner strives to achieve certain goals. One of the primary goals is profit, which should exist not only on paper but also on hand. In order to be able to earn a profit, it is necessary to take care of, among others o systematic reduction of operating costs of own business (Sikorski, 2008). Managing a transport company in crisis conditions is a set of activities and decisions, non-standard and uncertain, that are taken 
by a manager in particularly difficult economic conditions and market environment. That is why reasonable and effective management of a transport company, in the conditions of crisis and with constantly growing competition, is so important in the context of the current operation and achievement of the set business goals.

\section{Covid-19 and management of a transport company - the results of empirical research}

In order to determine the impact of the Covid-19 pandemic on the management of a transport company, surveys were carried out in Polish enterprises from the Podkarpackie and Lubelskie voivodships that conduct transport activities. The project of empirical research aimed at the implementation of the assumed goal of the article and the verification of the formulated hypothesis required the use of various research instruments. Therefore, a questionnaire and a case study were used. The first stage is a pilot study that was conducted on the basis of a questionnaire survey on a sample of 6 companies. Thanks to this study, the research tool was verified and methodological information was obtained that improved the course of the research process. The next stage included questionnaire research, which was essential for identifying the research areas in the author's area of interest. The questionnaires were completed in the period August-September 2020 by decision-makers in the surveyed transport companies (owner, president, director - CEO, manager), who deal with management on a daily basis. Questionnaires with cover letters were sent to 64 companies. The group (research sample) was selected in a non-random, purposeful manner. Finally, completed questionnaires were obtained from 19 companies, which gives a response rate of $29.7 \%$. The most important research results are presented in Figures 1 and 2 and Table 1.

In the first part of the survey, respondents answered the general question: "What is the level of impact of the Covid-19 pandemic on the management of your transport company"?

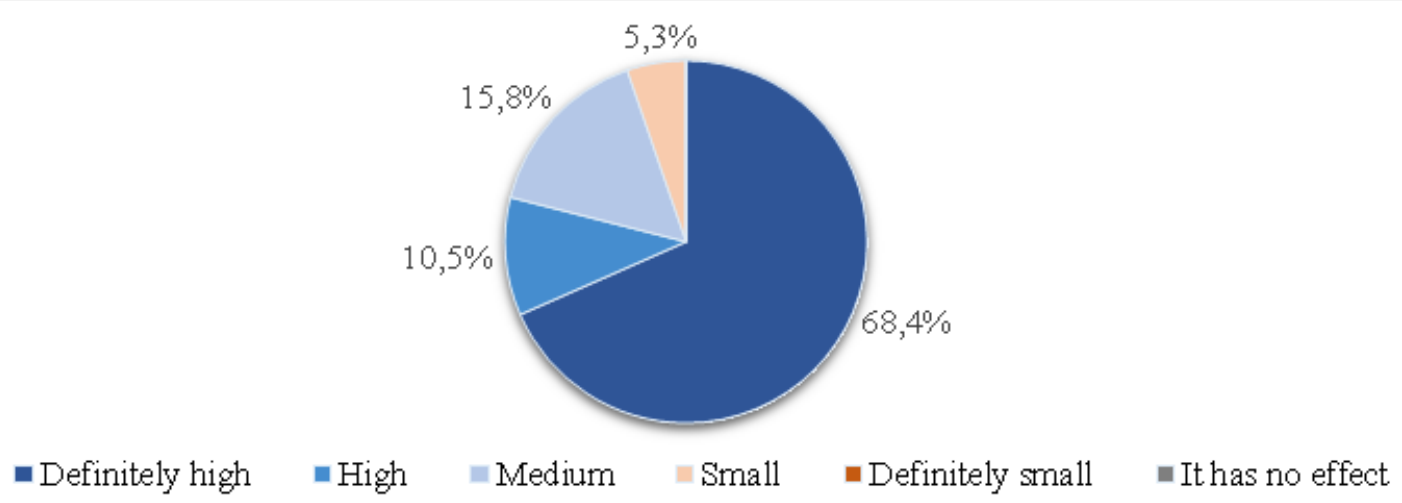

Figure 1. The level of Covid-19 impact on the management of a transportation company. Source: own study. 
$68.4 \%$ of the surveyed companies assess the level of the impact of the Covid-19 pandemic on the management of their transport company as definitely high (Figure 1), 10.5\% indicate the level of this impact as high, another $15.8 \%$ of the respondents described the level of the impact as medium, while only $5.3 \%$ ( 1 enterprise) believe that it is small. There was no answer about a definitely small level, as well as the respondents did not answer about the lack of the described impact. It follows that in total as many as $78.9 \%$ - 15 out of 19 surveyed enterprises perceive a high level of Covid-19 impact on the management of their transport company. The responses presented show that Covid-19 has a very large impact on the management of transport enterprises, it has a strong influence on them.

The next figure (Figure 2) presents the 4 most frequently indicated factors related to the Covid-19 pandemic situation, which, according to the respondents, had the greatest impact on the management and decisions (operational, tactical, strategic) in the surveyed transport companies.

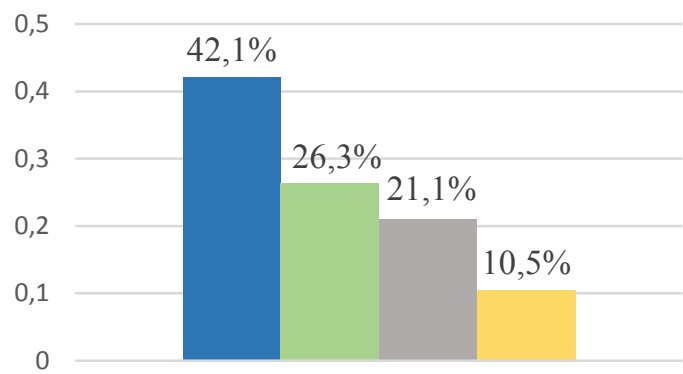

\footnotetext{
Decline or fear of a decline in transportation contracts

Losing customers to competing companies

Fear of reducing employment (dismissal of employees)

The risk of moving experienced employees (drivers) to another enterprise
}

Figure 2. Factors related to the situation of the Covid-19 pandemic that most influenced the management and decisions made in a transport company. Source: own study.

According to the opinion of respondents (Figure 2), the factor related to the Covid-19 pandemic situation that had the greatest impact on the management and decisions made in their transport company was the decline or fear of a decline in contracts for transport services (42.1\% of responses out of four with the greatest weight).

Below (Table 1) there are management decisions taken in the surveyed companies in order to limit the negative impact of the Covid-19 pandemic on their transport activities (in the period: March-August 2020). 
Table 1.

Management decisions taken to reduce the negative impact of the Covid-19 pandemic on transport activities

\begin{tabular}{|c|c|c|}
\hline Management decisions & $\begin{array}{l}\text { Number of } \\
\text { enterprises } \\
\text { (out of } 19 \\
\text { surveyed) } \\
\end{array}$ & Percentage \\
\hline $\begin{array}{l}\text { Ongoing familiarization with reliable sources of information about Covid-19, } \\
\text { i.e. governmental reports and relevant institutions, e.g. the Chief Sanitary } \\
\text { Inspector }\end{array}$ & 19 & $100 \%$ \\
\hline Obtaining funds from the government program "Anti-crisis shield" & 19 & $100 \%$ \\
\hline $\begin{array}{l}\text { Optimization (reduction) of operating costs, price negotiations with suppliers, } \\
\text { changing suppliers of goods and services, incl. cheaper fuel and spare parts for } \\
\text { vehicles, lower utility charges (change of operator), reduction of necessary } \\
\text { personnel and office expenses }\end{array}$ & 19 & $100 \%$ \\
\hline The strategy of continuous acquisition of new customers & 19 & $100 \%$ \\
\hline A more detailed (in-depth) analysis of the financial situation of contractors & 18 & $94,7 \%$ \\
\hline Suspension of investment plans, enterprise development & 17 & $89,5 \%$ \\
\hline $\begin{array}{l}\text { Increasing the group of service subcontractors and business contacts (greater } \\
\text { choice) }\end{array}$ & 16 & $84,2 \%$ \\
\hline Lowering prices for provided transport services & 16 & $84,2 \%$ \\
\hline Introducing remote work and similar forms of work for some employees & 14 & $73,7 \%$ \\
\hline Lowering the salary of employees & 14 & $73,7 \%$ \\
\hline Shortening the deferred payment deadline for provided transport services & 12 & $63,2 \%$ \\
\hline Reduction of employment (layoffs of drivers) & 10 & $52,6 \%$ \\
\hline Taking a working capital loan for current business activity & 7 & $36,8 \%$ \\
\hline Appointment of the anti-crisis staff in the company during the pandemic & 7 & $36,8 \%$ \\
\hline Taking a short-term loan in the current account & 5 & $26,3 \%$ \\
\hline Sale of trucks and other fixed assets in order to obtain additional funds & 5 & $26,3 \%$ \\
\hline Obtaining external funds from local and European funds & 5 & $26,3 \%$ \\
\hline Using the help of external managers & 3 & $15,8 \%$ \\
\hline $\begin{array}{l}\text { Advertising of transport services in the press, local television, } \\
\text { on billboards and leaflets }\end{array}$ & 2 & $10,5 \%$ \\
\hline Taking out an investment loan & 1 & $5,3 \%$ \\
\hline
\end{tabular}

Source: own study.

In all surveyed companies (100\%) decisions were made that concerned the current access to reliable sources of information about Covid-19, optimization (reduction) of operating costs, price negotiations with suppliers, obtaining funds from the government program "Anti-crisis shield", as well as a strategy of continuous acquisition of new customers (to support the declining demand for transport services). Only in one surveyed transport company a decision was made to take out an investment loan, which indicates that enterprises are afraid of an uncertain economic future and decided to suspend investments until the situation on the transport market improves.

\section{Summary}

Managing a transport company during the Covid-19 pandemic is a great challenge for managers, which they have to cope with in this difficult and uncertain time, if they want to 
continue to function in the transport market, generate income, or even invest and develop their business in the future. The work of managers is associated with making a large number of decisions that relate to current operations, planning and appropriate logistics, especially in international transport. Transport is a sector of the economy that is currently undergoing major changes. The Covid-19 pandemic, digital evolution, the coming green deal, legislative changes. All these elements will have a key impact on what transport will look like in the coming years. An important element securing the transport activity is diversification. The time of the Covid-19 pandemic has shown that focusing on one branch of transport is not always a good strategy in business. The freezing of the economy to fight the coronavirus has exposed transport companies to losses. Therefore, they often have to analyze their profitability, balance the currently conducted processes related to acquiring new freight and start building "financial pillows" that will allow them to maintain financial liquidity.

\section{References}

1. Bełch, P. (2019). Transport drogowy materiałów niebezpiecznych w obliczu „szarej strefy” na przykładzie przedsiębiorstwa handlowego z sektora paliw płynnych. Gospodarka Materiałowa i Logistyka, Vol. 1, pp. 16-21.

2. Chowell, G., Echevarría-Zuno, S., Viboud, C., Simonsen, L., Tamerius, J. (2011). Characterizing the Epidemiology of the 2009 influenza A/H1N1 Pandemic in Mexico. PLoS Med., Vol. 8, Iss. 5.

3. Dijkstra, L., Annoni, P., Kozovska, K. (2011). A New Regional Competitiveness Index: Theory, Methods and Findings. European Union Regional Policy, Vol. 2, pp. 3-26.

4. Długosz, J. (2009). Systemy transportowe, transport intermodalny. In: D. Kisperska-Moroń, and S. Krzyżaniak (Eds.), Logistyka. Biblioteka Logistyka (pp. 275-286). Poznań: Instytut Logistyki i Magazynowania.

5. Fearn-Banks, K. (2007). Crisis communications: A casebook approach. London: Routledge.

6. Gołembska, E., and Gołembski, M. (2020). Transport w logistyce. Warszawa: CeDeWu.

7. Grocki, R. (2020). Zarzadzanie kryzysowe. Warszawa: Difin.

8. Hirsch-Kreinsen, H. (2016). Digitization of industrial work: development paths and prospects. Journal for Labour Market Research, Vol. 49, Iss. 1. pp. 1-14.

9. Langinvainio, M. (2006). A Dozen Interpretations of Civilian Crisis Management. In: S. Korhonen, and J. Sumuvuori (Eds.), From Conflicts to Development (pp. 34-57). Jyväskylä: GKO. 
10. Lee, B.Y., Brown, S.T., Cooley, P., Potter M.A. (2010). Simulating School Closure Strategies to Mitigate an Influenza Epidemic. Journal of Public Health Management and Practice, Vol. 16, Iss. 3. pp. 252-261.

11. Lee, J., Bagheri B., Kao, H.A. (2015). A cyber-physical systems architecture for Industry 4.0 - based manufacturing systems. Manufacturing Letters, Vol. 3, pp. 18-23.

12. Marecki, K., Wieloch, M. (2008). Biznesplan. Elementy planowania działalności rozwojowej. Warszawa: SGH.

13. Neider, J. (2019). Transport międzynarodowy. Warszawa: PWE.

14. Rinaldi, S.M., Peerenboom, J.P., Kelly, T.K. (2001). Identifying, understanding, and analyzing critical infrastructure interdependencies. IEEE Control Systems Magazine, Vol. 21, Iss. 6. pp. 11-25.

15. Rosa, G. (2013). Konkurencja na rynku ustug transportowych. Warszawa: C.H. Beck.

16. Sikorski, P.M. (2008). Spedycja w praktyce - wiek XXI. Warszawa: PWT.

17. Skomra, W. (2020). Nowe oblicze zarządzania ryzykiem jako konsekwencja rosnącej zmienności otoczenia. In: G. Gierszewska (Ed.), Zarzadzanie w przedsiębiorstwie N.0. Droga do przyszłości (pp. 214-234). Warszawa: Politechnika Warszawska.

18. Strandhagen, J., Alfnes, E., Strandhagen, J.O., Vallandingham, L. (2017). The fit of Industry 4.0 applications in manufacturing logistics: a multiple case study. Advances in Manufacturing, Vol. 5, pp. 344-358. 